\title{
Nitrate Nitrogen Movement through the Soil Profile beneath a Containerized Greenhouse Crop Irrigated with Two Leaching Fractions and Two Wetting Agent Levels
}

\author{
Richard J. McAvoy \\ Department of Plant Science, University of Connecticut, Storrs, CT 06269-4067
}

Additional index words. leaching intensity, chrysanthemum

\begin{abstract}
Rose Grenadine' and 'Buckaroo' garden chrysanthemums [Dendranthema $\times$ grandiflorum (Ramat.) Kitamura] were produced in $15-\mathrm{cm}$ pots in the greenhouse and fertilized with either 550 or $1000 \mathrm{ml}$ of a $15 \mathrm{~mol} \cdot \mathrm{m}^{-3} \mathrm{~N}$ solution at each irrigation. The nutrient solution applied to half the pots contained a wetting agent (WA), and the remaining pots received no WA. Core samples were removed at $15-\mathrm{cm}$ increments to a depth of $90 \mathrm{~cm}$ from the soil beneath the pots. The average leaching fraction (LF) from pots receiving a WA was 0.29 but was 0.26 from pots receiving no WA. However, WA did not affect the leachate $\mathrm{NO}_{3}-\mathrm{N}$ concentration or the total $\mathrm{NO}_{3}-\mathrm{N}$ deposited on the soil beneath; these were most influenced by LF. After week 2, $\mathrm{NO}_{3}-\mathrm{N}$ concentration in the upper $15 \mathrm{~cm}$ soil layer was 3.4 times higher with a high $\mathrm{LF}$ than with a low $\mathrm{LF}$ (30 and $8.8 \mathrm{~g} \cdot \mathrm{m}^{-3}$ respectively). At week 10, the $\mathrm{NO}_{3}-\mathrm{N}$ concentration in the 30 to $45 \mathrm{~cm}$ soil layer averaged $71.9 \mathrm{~g} \cdot \mathrm{m}^{-}$ ${ }^{3}$ under the high $L F$ and $35.5 \mathrm{~g} \cdot \mathrm{m}^{-3}$ under the low $\mathrm{LF}$. Total $\mathrm{N}$ and $\mathrm{NO}_{3}-\mathrm{N}$ in the potting medium was higher in the low $\mathrm{LF}$ pots than the high $\mathrm{LF}$ pots, while $\mathrm{NO}_{3}-\mathrm{N}$ was higher in the medium of pots irrigated without WA than with WA. Final plant shoot mass was higher in pots irrigated to a high LF or without WA than in pots irrigated to a low LF or with WA.
\end{abstract}

Greenhouse crop management practices that contribute to $\mathrm{NO}_{3}-\mathrm{N}$ loading to the soil profile are regarded as a threat to groundwater quality and are of concern to the commercial industry and the public. Surveys conducted in Europe (Molitor, 1990) and the United States (Walker, 1990) report that excessively high $\mathrm{N}$ concentrations $\left(>200 \mathrm{~g} \cdot \mathrm{m}^{-3}\right)$ can be found in the top meter of soil underlying commercial greenhouses. More recently, $\mathrm{NO}_{3}-\mathrm{N}$ concentrations $>230 \mathrm{~g} \cdot \mathrm{m}^{-3}$ in the top meter of soil have been measured under decades-old greenhouses in Connecticut (McAvoy, 1991).

The leaching fraction (LF) or the portion of the irrigation volume that leaches from a pot greatly influences the electrical conductivity (EC) in the potting medium and the leachate ( $\mathrm{Ku}$ and Hershey, 1991, 1992; Yelanich and Biernbaum, 1990). Ruter (1992) reported a direct, positive linear relationship between EC and $\mathrm{NO}_{3}-\mathrm{N}$ level in the potting medium extract.

One of the few studies to characterize the fate of $\mathrm{NO}_{3}-\mathrm{N}$ in the soil profile underlying a containerized greenhouse crop reported that LF also exerted a direct, positive effect on $\mathrm{NO}_{3}-\mathrm{N}$ accumulation and movement in the soil profile (McAvoy et al., 1992). With poinsettia stock plants irrigated with a high $\mathrm{LF}, \mathrm{NO}_{3}-\mathrm{N}$ accumulated at higher concentrations and moved deeper into the soil profile than with a low LF.

Although limited data are available to relate crop management practices to soil loading of $\mathrm{NO}_{3}-\mathrm{N}$ in the greenhouse, many factors are known to affect the water-holding properties of potting media and subsequent leachate quality. For example, irrigation method and medium amendments affect the water-holding capacity of potting media. In one study (Elliott, 1992), the highest effective water-holding capacity for various peat-lite media was observed when overhead irrigation, hydrophilic gels, or wetting agents

Received for publication 1 June 1993. Accepted for publication 16 Sept. 1993 Storrs Agricultural Experiment Station scientific contribution 1484. This research was funded in part by the U.S. Dept. of Agriculture Extension Service under special project 90-EWQI-1-9212 and the Univ. of Connecticut Center for Environmental Health. Plant material was provided by Bristol Mums, Bristol, Conn. The cost of publishing this paper was defrayed in part by the payment of page charges. Under postal regulations, this paper therefore must be hereby marked advertisement solely to indicate this fact.
(WAs) were used. Leachates from hydrogel-amended media have higher ECs than leachates from media without hydrogel (Wang and Boogher, 1987); the effect of hydrogel on LF was not reported. Greenhouse operators often add WAs to the irrigation solution to facilitate rewetting dry peat-lite media.

The use of controlled-release fertilizers (CRFs) to reduce the release of nitrate into the environment has been the focus of many investigations (Brand et al., 1993; Cox, 1993; Hershey and Paul, 1982; Poole and Conover, 1989; Rathier and Frink, 1989; Williams and Nelson, 1990). Rathier and Frink (1989) concluded that N runoff could be reduced by use of CRFs rather than water-soluble fertilizers. However, Hershey and Paul (1982) and, later, Cox (1993) found that leachate $\mathrm{NO}_{3}-\mathrm{N}$ could be as high or higher with CRFs than with water-soluble forms. Cox found that split applications and top dressing of CRFs were more effective at reducing $\mathrm{N}$ leaching than single applications and medium incorporation of CRFs.

Brand et al. (1993) reported that soil loading and downward movement of $\mathrm{NO}_{3}-\mathrm{N}$ under containerized nursery crops fertilized with CRFs was influenced by the plant species grown. The rapidly growing Cornus amomum removed more $\mathrm{N}$ than the slow-growing Rhododendron 'Cary's Red', resulting in less $\mathrm{NO}_{3}-\mathrm{N}$ in the soil profile under the $C$. amomum. Ku and Hershey (1992) recognized that specific crop water-use patterns influence the total quantity of leachate. Plants using high quantities of water (geraniums) required more frequent irrigation than those using less water (poinsettia); therefore, even when the LF remained unchanged, the leaching intensity (LI) of frequently irrigated potting media increased. LI is defined as the number of container capacities leached per week.

Although the high $\mathrm{N}$ concentrations measured in the soil beneath greenhouses in the United States and Europe suggest a potentially significant source of environmental contamination, these data alone do not indicate how specific crop management practices contribute to nitrate loading to groundwater. The greenhouse differs from outdoor containerized plant production because of the exclusion of rainfall. In the greenhouse, hydraulic loading is totally controlled by the crop management practices used. Therefore, examining existing greenhouse crop management practices 
with regard to $\mathrm{NO}_{3}-\mathrm{N}$ loading and movement through the underlying soil profile is an important first step in characterizing this dynamic relationship.

The objective of this study was to quantify changes over time in the $\mathrm{NO}_{3}-\mathrm{N}$ profile in the top $0.9 \mathrm{~m}$ of soil underlying a greenhouse chrysanthemum crop irrigated with or without the liquid WA AquaGro L (47\% polyoxyethylene esters of cyclic acids, $47 \%$ polyoxyethylene esters of alkylated phenols and $6 \%$ silicone antifoam emulsion) to produce either a low or high LF.

\section{Materials and Methods}

On 9 July 1991, rooted 'Rose Grenadine' and 'Buckaroo' garden chrysanthemum cuttings were planted in Metro 360, a commercial peat-lite medium with a bulk density of $0.3 \mathrm{~g} \cdot \mathrm{cm}^{-3}$ (Grace-Sierra, Cambridge, Mass.). Two rooted cuttings (one of each cultivar) were planted in a $15-\mathrm{cm}$ plastic pot (bulk volume $=1.8$ liters). Immediately after transplant, pots were irrigated with $28.6 \mathrm{~mol} \cdot \mathrm{m}^{-3} \mathrm{~N}$ solution (400 $\mathrm{mg} \cdot$ liter $^{-1}$ ) formulated with $15 \mathrm{~N}-7 \mathrm{P}-14.1 \mathrm{~K}$ water-soluble fertilizer, pinched, and placed in the greenhouse. Plants were pinched a second time on 29 July 1991. A long-day photoperiod was provided from transplant until 29 Aug. 1991 using $2 \mu \mathrm{mol} \cdot \mathrm{m}^{-2} \cdot \mathrm{s}^{-1}$ incandescent lighting from 2200 to $0200 \mathrm{HR}$.

On 5 Aug. 1991, chrysanthemums were placed atop 16identical soil-filled boxes at a density of 24 pots $/ \mathrm{m}^{2}$. The inside dimensions of each box were $1 \mathrm{~m}$ (depth) $\times 1 \mathrm{~m}$ (length) $\times 0.5 \mathrm{~m}$ (width). Pots were spaced on $20-\mathrm{cm}$ centers with 12 pots/box. Plants on half the boxes were irrigated with $550 \mathrm{ml}$ of nutrient solution at each irrigation, the other half was irrigated with $1000 \mathrm{ml}$ to produce a low and a high LF (targeted LF $=0.1$ or 0.5 respectively). Half the pots in each LF treatment received a nutrient solution containing AquaGro L at an initial concentration of 2000 and $50 \mathrm{mg} \cdot$ liter $^{-1}$ with each subsequent irrigation. The remaining pots received no WA. The nutrient solution applied to all plants contained $15 \mathrm{~mol}$ $\mathrm{N} / \mathrm{m}^{3}\left(210 \mathrm{mg} \cdot\right.$ liter $\left.^{-1}\right)$ from a $15 \mathrm{~N}-7 \mathrm{P}-14.1 \mathrm{~K}\left(8 \% \mathrm{NO}_{3}-\mathrm{N}, 3.18 \%\right.$ $\mathrm{NH}_{4}-\mathrm{N}$, and 3.82\% urea-N) soluble fertilizer (Grace-Sierra). Treatments were arranged in a randomized complete-block design, using four identical boxes located side by side. Each block was replicated four times.

Wooden boxes were recessed $0.6 \mathrm{~m}$ into the excavated earthen floor of a greenhouse and filled with soil screened through 1.6-cm hardware cloth. Boxes were bottomless to establish contact with the subsoil. The native soils underlying the greenhouse were placed in the boxes in stratified layers of similar depth to those in the preexisting greenhouse soil profile. The top $19 \mathrm{~cm}$ layer was a coarse sand $(1.5 \%$ OM, bulk density $1.61 \mathrm{~g} \cdot \mathrm{cm}^{-3}$ ), the next $51 \mathrm{~cm}$ layer was a silty loam $\left(3.2 \% \mathrm{OM}\right.$, bulk density $\left.1.31 \mathrm{~g} \cdot \mathrm{cm}^{-3}\right)$, and the bottom $30-\mathrm{cm}$ layer was a clay loam $\left(3.4 \% \mathrm{OM}\right.$, bulk density $\left.1.26 \mathrm{~g} \cdot \mathrm{cm}^{-3}\right)$. As each $15-$ $\mathrm{cm}$ layer of soil was added to the box, final bulk density was achieved by applying a uniform pressure of $35 \mathrm{~kg} \cdot \mathrm{m}^{-2}$. Soil in the boxes was compacted to simulate the conditions in a commercial greenhouse. Before the start of the study, the soil was leached with tap water daily (from 12 July to 1 Aug. 1991) to reduce the $\mathrm{NO}_{3}-\mathrm{N}$ remaining in the profile from a previous study conducted in 1990 (McAvoy et al., 1992). Residual $\mathrm{NO}_{3}-\mathrm{N}$ levels were determined at the start of the experiment (week 0) by sampling the leached soil profile before applying the experimental treatments.

Plants were irrigated when the potting medium became dry, every 5 days on average (Fig. 1A). Nutrient solutions were applied by hand directly to all 12 pots on each box using a graduated cylinder. Leachate was collected from each of three pots within each treatment group, and the actual leachate volume was measured using a graduated cylinder. Leachate was then returned to the soil surface beneath the pots from which it was collected. However, at $\approx 2$-week intervals, a 15 -ml leachate sample was retained for analysis. These samples were frozen and stored at $-60 \mathrm{C}$ in an ultra-low temperature freezer. Actual leachate volume and initial irrigation volume were used to calculate LF (i.e., LF = volume leached/volume applied).

At 2-week intervals from 5 Aug. to 14 Oct. 1991, a soil profile in $15-\mathrm{cm}$ layers to $0.9 \mathrm{~m}$ was obtained from each box using a 1.9$\mathrm{cm}$-diameter Dutch auger. Each box was divided into 1- $\mathrm{dm}^{2}$ squares providing 50 possible sample sites, and two soil cores were randomly selected from each box on each sampling date. Samples were immediately spread in a thin layer $(1 \mathrm{~cm})$ and dried overnight at ambient temperature (20 to $25 \mathrm{C}$ ) in a continuously ventilated room. Dried samples were then screened and stored in acidwashed bottles for future analysis. After removing samples, auger holes were refilled with soil to prevent channeling and the location was marked so that sites were not resampled.

Two pots of chrysanthemums were harvested from each treatment box on 7 Sept. (day 33), and three plants per box were collected at final harvest on 14 Oct. (day 70). Plant tissue was dried at 70C and ground to pass a 40-mesh screen, and potting medium samples were collected from the harvested pots and dried for analysis.

Nitrate $\mathrm{N}$ was extracted from 2-g soil samples with $20 \mathrm{ml}$ of 2 $\mathrm{M} \mathrm{KCl}$, and from 0.3 -g potting medium samples with $25 \mathrm{ml}$ of $2 \mathrm{M}$ $\mathrm{KCl}$. With plant tissue, $0.2-\mathrm{g}$ samples were extracted in $40 \mathrm{ml}$ deionized water. All samples were shaken for $30 \mathrm{~min}$ in the extract solution before filtering. Nitrate was quantitatively analyzed using the copperized cadmium reduction method (Keeney and Nelson, 1982) according to the automated procedure for the auto-analyzer (Scientific Instruments Corp., Pleasantville, N.Y.). Total $\mathrm{N}$ in plant tissue and potting medium samples was determined with a thermal conductivity N determinator (LP-428; LECO Corp., St. Joseph, Mich.).

Nitrate $\mathrm{N}$ concentrations in the soil profiles underlying each irrigation volume by WA treatment were compared at each depth on each sample date using two-way analysis of variance procedures (Gomez and Gomez, 1984). Cultivar effects were determined using split-plot analysis. The effects of LF treatments over time on $\mathrm{NO}_{3}-\mathrm{N}$ concentrations at each soil depth were determined using a split-plot analysis over time and single-degree-of-freedom orthogonal contrasts (Gomez and Gomez, 1984).

\section{Results}

Actual LF at each irrigation varied considerably but, in general, 1000-ml irrigations produced large LFs and 550-ml irrigations produced smaller LFs (Fig. 1A). The LF from pots that received $1000 \mathrm{ml}$ of nutrient solution averaged 0.44 during the study, while the LF from pots that received $550 \mathrm{ml}$ averaged 0.12 (Fig. 1A). The effect of WA on LF was more subtle than that of LF treatment, but significant over the course of the study (Table 1, Fig. 1A). Pots irrigated with AquaGro L had an average LF of 0.29, while pots receiving no WA had a LF of 0.26 averaged over the 10 -week study. For the 10-week study, 15 liters of leachate was deposited per square meter of soil surface with a low LF without WA and 21.2 liters $\cdot \mathrm{m}^{-2}$ with WA. With a high LF, cumulative leachate was 122 liters $\cdot \mathrm{m}^{-2}$ without WA and 125.2 liters $\mathrm{m}^{-2}$ with WA.

Although WA affected LF, it did not affect the average $\mathrm{NO}_{3}-\mathrm{N}$ concentration in the leachate (Fig. 1B). Leachate $\mathrm{NO}_{3}-\mathrm{N}$ concentration was only affected by LF. Pots with a high LF had leachate with 200 to $300 \mathrm{mg} \cdot \mathrm{liter}^{-1} \mathrm{NO}_{3}-\mathrm{N}$, while pots with a low $\mathrm{LF}$ had leachate with 300 to $650 \mathrm{mg} \cdot \mathrm{liter}^{-1} \mathrm{NO}_{3}-\mathrm{N}$. Initially, leachate $\mathrm{NO}_{3}-\mathrm{N}$ concentrations were similar for all treatments. However, 
the leachate $\mathrm{NO}_{3}-\mathrm{N}$ concentration with low $\mathrm{LF}$ rapidly increased over time, while it was relatively unchanged with a high LF.

The LF was the overriding factor influencing total $\mathrm{NO}_{3}-\mathrm{N}$ deposition onto the underlying soil profile (Fig. 1C). The average irrigation deposition was $33.2 \mathrm{mg} \mathrm{NO}-\mathrm{N} /$ pot $\left(0.69 \mathrm{~g} \cdot \mathrm{m}^{-2}\right)$ with a low $\mathrm{LF}$ and $108.6 \mathrm{mg} \mathrm{NO}-\mathrm{N} /$ pot $\left(2.38 \mathrm{~g} \cdot \mathrm{m}^{-2}\right)$ with a high $\mathrm{LF}$.

In the potting medium, differences in total $\mathrm{N}$ and $\mathrm{NO}_{3}-\mathrm{N}$ concentration were detected in response to $\mathrm{LF}$ after 33 days or six irrigations (Table 1). Nitrate $\mathrm{N}$ and total $\mathrm{N}$ were $25 \%$ to $27 \%$ lower in the potting

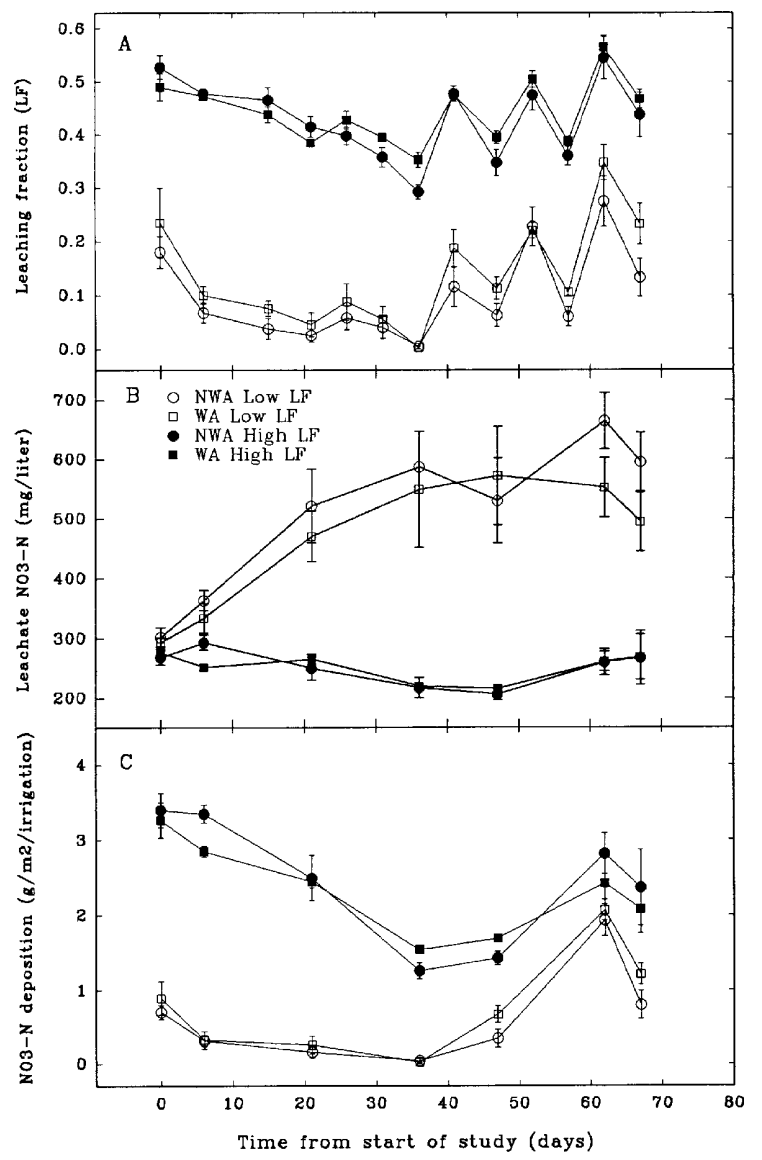

Fig. 1. Mean leaching fraction $(\mathrm{LF})(\mathbf{A})$, leachate $\mathrm{NO}_{3}-\mathrm{N}$ concentration $(\mathbf{B})$, and $\mathrm{NO}_{3}-$ $\mathrm{N}$ deposition from potted chrysanthemums irrigated to a low or high LF with or without the wetting agent AquaGro L during a 10-week study. Vertical bars represent SE of the means; error bars that do not appear on graphs are smaller than symbols. medium with a high LF than with a low LF. After 33 days, WA had no effect on medium $\mathrm{NO}_{3}-\mathrm{N}$ concentration, but, after 70 days or 13 irrigations, medium $\mathrm{NO}_{3}-\mathrm{N}$ was $19 \%$ higher without WA than with WA (Table 1). After 13 irrigations, total $\mathrm{N}$ and $\mathrm{NO}_{3}-\mathrm{N}$ levels were higher in the medium with a low LF than a high LF.

Neither LF nor WA affected shoot dry mass or leaf total $\mathrm{N}$ or $\mathrm{NO}_{3}-\mathrm{N}$ after 33 days, but there were cultivar differences (Table 2). Leaf total N was higher for 'Buckaroo' (5.01\% of dry mass), than for 'Rose Grenadine' (4.81\% of dry mass), while leaf $\mathrm{NO}_{3}-\mathrm{N}$ was lower in 'Buckaroo' ( $0.80 \%$ of dry mass) than in 'Rose Grenadine' ( $0.88 \%$ of dry mass). At the end of the study, WA and LF affected shoot dry mass and leaf total $\mathrm{N}$ and $\mathrm{NO}_{3}-\mathrm{N}$ levels (Table 2). Chrysanthemums irrigated with a WA accumulated $10 \%$ less shoot dry mass and had lower total $\mathrm{N}$ and lower $\mathrm{NO}_{3}-\mathrm{N}$ levels in leaves than mums not exposed to the WA. LF also affected total shoot dry mass and leaf total $\mathrm{N}$ levels at 10 weeks. Mums with a high LF produced $14.3 \%$ more shoot dry mass with lower leaf total $\mathrm{N}$ levels than plants with a low LF.

A significant interaction between WA and LF occurred with leaf total $\mathrm{N}$ (Table 2). At low LFs, leaf total $\mathrm{N}$ was the same with or without WA (5.15\% of dry mass). However, with a high LF, leaf total $\mathrm{N}$ was lower with WA than without $(5.04 \%$ and $5.22 \%$ of dry mass respectively). The total $\mathrm{N}$ and $\mathrm{NO}_{3}-\mathrm{N}$ levels of flowers were not affected by WA or LF; however, significant cultivar differences were found for these factors. After 70 days, total $\mathrm{N}$ was higher in 'Buckaroo' flowers (4.63\% of dry mass) than 'Rose Grenadine' flowers (4.52\% of dry mass), while the $\mathrm{NO}_{3}-\mathrm{N}$ level in 'Buckaroo' was lower than in 'Rose Grenadine' (0.08\% and 0.16\% of dry mass respectively). At flowering, 'Buckaroo' shoot dry mass was $45 \%$ higher than 'Rose Grenadine'.

Once nitrate-containing leachate was deposited on the soil beneath the crop, LF was the only factor associated with significant changes in nitrate movement and accumulation in the soil profile (Table 3). Therefore, soil $\mathrm{NO}_{3}-\mathrm{N}$ levels are averages for the high and low LF treatments only (Figs. 2 and 3). Initially, the $\mathrm{NO}_{3}-\mathrm{N}$ level at each soil depth was the same for both LFs (Fig. 2, week 0) even though the absolute level of residual $\mathrm{NO}_{3}-\mathrm{N}$ in the profile from a previous study (McAvoy et al., 1992) varied with depth.

After 2 weeks, the $\mathrm{NO}_{3}-\mathrm{N}$ concentration in the top 15-cm layer of soil was $340 \%$ greater with a high LF than with a low LF. After 4 weeks, the $\mathrm{NO}_{3}-\mathrm{N}$ concentration was $272 \%$ higher in the 15 to 30 $\mathrm{cm}$ soil layer with a high LF than with a low LF (Fig. 2), and the $\mathrm{NO}_{3}-\mathrm{N}$ levels in the 0 to $15 \mathrm{~cm}$ layer continued to increase with a high LF. These differences in $\mathrm{NO}_{3}-\mathrm{N}$ accumulation in the upper 30

Table 1. Average leaching fraction (LF), leachate $\mathrm{NO}_{3}-\mathrm{N}$ concentration $\left(\mathrm{mg} \cdot \mathrm{liter}^{-1}\right)$, and $\mathrm{NO}_{3}-\mathrm{N}$ deposition per irrigation $\left(\mathrm{g} \cdot \mathrm{m}^{-2}\right)$ from pots irrigated with a low or high LF either with the wetting agent (WA) AquaGro L or without (NWA), and potting medium total $\mathrm{N}_{\text {and }} \mathrm{NO}_{3}-\mathrm{N}$ concentration from samples collected on days 33 and 70 of a 10 -week study period. LF was determined at each irrigation or 13 times during the study, and leachate $\mathrm{NO}_{3}-\mathrm{N}$ concentration and $\mathrm{NO}_{3}-\mathrm{N}$ deposition were determined about every other irrigation or seven times during the study period.

\begin{tabular}{|c|c|c|c|c|c|c|c|}
\hline \multirow[b]{3}{*}{ Treatment } & \multicolumn{3}{|c|}{ Average for 10 -week period } & & & & \\
\hline & \multirow[b]{2}{*}{$\mathrm{LF}$} & \multirow{2}{*}{$\begin{array}{c}\text { Leachate } \\
\mathrm{NO}_{3}-\mathrm{N} \\
\text { concn } \\
\left(\mathrm{mg} \cdot \operatorname{liter}^{-1}\right)\end{array}$} & \multirow{2}{*}{$\begin{array}{c}\mathrm{NO}_{3}-\mathrm{N} \\
\text { deposition } \\
\text { per irrigation } \\
\left(\mathrm{g} \cdot \mathrm{m}^{-2}\right)\end{array}$} & \multicolumn{2}{|c|}{ Day 33 sample } & \multicolumn{2}{|c|}{ Day 70 sample } \\
\hline & & & & $\begin{array}{l}\text { Total N } \\
\text { (\% dry } \\
\text { mass) }\end{array}$ & $\begin{array}{c}\mathrm{NO}_{3}-\mathrm{N} \\
\left(\mathrm{g} \cdot \mathrm{m}^{-3}\right. \\
\text { medium })\end{array}$ & $\begin{array}{l}\text { Total } \mathrm{N} \\
\text { (\% dry } \\
\text { mass) }\end{array}$ & $\begin{array}{c}\mathrm{NO}_{3}-\mathrm{N} \\
\left(\mathrm{g} \cdot \mathrm{m}^{-3}\right. \\
\text { medium })\end{array}$ \\
\hline$\overline{\mathrm{NWA}}$ & 0.26 & 349 & 1.53 & 0.47 & 434 & 0.41 & 447 \\
\hline WA & 0.29 & 343 & 1.56 & 0.43 & 388 & 0.40 & 375 \\
\hline Low LF & 0.12 & 441 & 0.69 & 0.51 & 474 & 0.49 & 534 \\
\hline High LF & 0.44 & 251 & 2.38 & 0.39 & 348 & 0.31 & 288 \\
\hline \multicolumn{8}{|l|}{ Effects } \\
\hline WA & $P \leq 0.05$ & NS & NS & NS & NS & NS & $P \leq 0.05$ \\
\hline $\mathrm{LF}$ & $P \leq 0.01$ & $P \leq 0.01$ & $P \leq 0.01$ & $P \leq 0.01$ & $P \leq 0.01$ & $P \leq 0.01$ & $P \leq 0.01$ \\
\hline
\end{tabular}


Table 2. Total shoot dry mass, and total $\mathrm{N}$ and $\mathrm{NO}_{3}-\mathrm{N}$ as a percentage of dry mass in leaf and flower tissue of chrysanthemums 'Buckaroo' and 'Rose Grenadine' irrigated with a nutrient solution containing either a wetting agent (WA) or no WA (NWA) to produce a high or low leaching fraction (LF). Plants were harvested 33 and 70 days after the treatments began.

\begin{tabular}{|c|c|c|c|c|c|c|c|c|}
\hline \multirow[b]{3}{*}{ Treatment } & \multirow{2}{*}{\multicolumn{2}{|c|}{$\begin{array}{c}33 \text { Days } \\
\text { Leaf }\end{array}$}} & \multicolumn{4}{|c|}{70 Days } & & \\
\hline & & & \multicolumn{2}{|c|}{ Leaf } & \multicolumn{2}{|c|}{ Flowers } & \multicolumn{2}{|c|}{ Shoot dry mass } \\
\hline & $\begin{array}{c}\text { Total N } \\
(\%)\end{array}$ & $\begin{array}{c}\mathrm{NO}_{3}-\mathrm{N} \\
(\%)\end{array}$ & $\begin{array}{c}\text { Total N } \\
(\%)\end{array}$ & $\begin{array}{c}\mathrm{NO}_{3}-\mathrm{N} \\
(\%)\end{array}$ & $\begin{array}{c}\text { Total N } \\
(\%)\end{array}$ & $\begin{array}{c}\mathrm{NO}_{3}-\mathrm{N} \\
(\%)\end{array}$ & $\begin{array}{c}33 \text { Days } \\
(\mathrm{g})\end{array}$ & $\begin{array}{c}70 \text { Days } \\
(\mathrm{g})\end{array}$ \\
\hline \multicolumn{9}{|c|}{ Buckaroo } \\
\hline \multicolumn{9}{|l|}{ Low LF } \\
\hline NWA & 4.99 & 0.80 & 5.15 & 0.71 & 4.51 & 0.07 & 3.3 & 10.3 \\
\hline WA & 5.07 & 0.82 & 5.15 & 0.70 & 4.69 & 0.09 & 3.2 & 9.4 \\
\hline \multicolumn{9}{|l|}{ High LF } \\
\hline NWA & 4.91 & 0.77 & 5.22 & 0.72 & 4.71 & 0.08 & 3.7 & 13.5 \\
\hline WA & 5.08 & 0.81 & 5.04 & 0.62 & 4.61 & 0.07 & 3.6 & 11.1 \\
\hline \multicolumn{9}{|c|}{ Rose Grenadine } \\
\hline \multicolumn{9}{|l|}{ Low LF } \\
\hline NWA & 4.84 & 0.88 & 4.57 & 0.75 & 4.41 & 0.16 & 3.7 & 8.0 \\
\hline WA & 4.88 & 0.90 & 4.55 & 0.66 & 4.55 & 0.15 & 3.0 & 7.2 \\
\hline \multicolumn{9}{|l|}{ High LF } \\
\hline No WA & 4.83 & 0.97 & 4.55 & 0.74 & 4.66 & 0.18 & 3.5 & 7.6 \\
\hline WA & 4.7 & 0.78 & 4.29 & 0.59 & 4.45 & 0.13 & 3.4 & 7.7 \\
\hline \multicolumn{9}{|c|}{ Main effects and significant interactions } \\
\hline Cultivar & $P \leq 0.05$ & $P \leq 0.05$ & $P \leq 0.01$ & NS & $P \leq 0.05$ & $P \leq 0.01$ & NS & $P \leq 0.01$ \\
\hline WA & NS & NS & $P \leq 0.01$ & $P \leq 0.01$ & NS & NS & NS & $P \leq 0.05$ \\
\hline LF & NS & NS & $P \leq 0.01$ & NS & NS & NS & NS & $P \leq 0.01$ \\
\hline $\mathrm{WA} \times \mathrm{LF}$ & NS & NS & $P \leq 0.01$ & NS & NS & NS & NS & NS \\
\hline
\end{tabular}

Table 3. Summary of significant leaching fraction (LF) treatment effects and contrasts by sample depth over time for soil $\mathrm{NO}_{3}-\mathrm{N}_{\text {concentration }}$ $\left(\mathrm{g} \cdot \mathrm{m}^{-3}\right)$. Wetting agent did not significantly affect soil $\mathrm{NO}_{3}-\mathrm{N}$ levels at any depth or during any of the time periods sampled.

\begin{tabular}{|c|c|c|c|c|c|}
\hline \multirow{2}{*}{$\begin{array}{l}\text { Time } \\
\text { interval }\end{array}$} & \multirow{2}{*}{$\begin{array}{c}\text { Treatment } \\
\text { effect }\end{array}$} & \multicolumn{4}{|c|}{ Average sample depth (cm) } \\
\hline & & $0-15$ & $15-30$ & $30-45$ & $45-90$ \\
\hline Week 0 & LF & NS & NS & NS & NS \\
\hline Week 2 & $\mathrm{LF}$ & $P \leq 0.01$ & $P \leq 0.05$ & NS & NS \\
\hline Week 4 & $\mathrm{LF}$ & $P \leq 0.01$ & $P \leq 0.01$ & NS & NS \\
\hline Week 6 & $\mathrm{LF}$ & $P \leq 0.01$ & $P \leq 0.01$ & NS & NS \\
\hline Week 8 & $\mathrm{LF}$ & $P \leq 0.05$ & $P \leq 0.01$ & NS & NS \\
\hline Week 10 & $\mathrm{LF}$ & NS & $P \leq 0.01$ & $P \leq 0.05$ & NS \\
\hline \multicolumn{6}{|c|}{ Weeks 0 through 10} \\
\hline & $\mathrm{LF}$ & $P \leq 0.01$ & $P \leq 0.01$ & NS & NS \\
\hline & Time & $P \leq 0.01$ & $P \leq 0.01$ & $P \leq 0.01$ & $P \leq 0.05$ \\
\hline & $\mathrm{T} \times \mathrm{LF}$ & $P \leq 0.05$ & $P \leq 0.01$ & $P \leq 0.01$ & NS \\
\hline & $\mathrm{T} \times \mathrm{LF}_{\text {Linear }}$ & $P \leq 0.01$ & $P \leq 0.01$ & $P \leq 0.01$ & NS \\
\hline & $\mathrm{T} \times \mathrm{LF}_{\text {Quadratic }}$ & NS & NS & $P \leq 0.01$ & NS \\
\hline
\end{tabular}

cm soil layers between high and low LF also occurred in weeks 6 and 8 (Fig. 2, Table 2). At 10 weeks, however, $\mathrm{NO}_{3}-\mathrm{N}$ levels were also $203 \%$ higher in the 30 to $45 \mathrm{~cm}$ zone with a high LF than with a low LF. In the 45 to 60,60 to 75 , and 75 to $90 \mathrm{~cm}$ layers, $\mathrm{NO}_{3}-\mathrm{N}$ levels did not differ with LF throughout the 10-week study (Fig. 2).

In the 0 to $15 \mathrm{~cm}$ and 15 to $30 \mathrm{~cm}$ soil layers, there were linear interactions between $\mathrm{LF}$ and $\mathrm{NO}_{3}-\mathrm{N}$ accumulation over time (Table 3, Fig. 3). The rate of $\mathrm{NO}_{3}-\mathrm{N}$ accumulation was $212 \%$ higher in the 0 to $15 \mathrm{~cm}$ layer and $454 \%$ higher in the 15 to $30 \mathrm{~cm}$ layer with a high LF than with a low LF. In the 30 to $45 \mathrm{~cm}$ layer, the interaction between LF and time differed linearly and quadratically with respect to $\mathrm{NO}_{3}-\mathrm{N}$ accumulation (Table 3 ). In this layer, little change in $\mathrm{NO}_{3}-\mathrm{N}$ concentration was detected during the first 28 days; however, between day 42 and day 70, the $\mathrm{NO}_{3}-\mathrm{N}$ concentration with a high LF increased rapidly, while it changed much more gradually with a low LF.
Overall, in the 0 to $45 \mathrm{~cm}$ soil zone, $\mathrm{NO}_{3}-\mathrm{N}$ accumulated linearly over time according to the equation $\left[\mathrm{NO}_{3}-\mathrm{N}\left(\mathrm{g} \cdot \mathrm{m}^{-3}\right)\right]=6.49+0.419$ $\times$ days $\left(r^{2}=0.95\right)$ for the low $\mathrm{LF}$ treatment, and $\left[\mathrm{NO}_{3}-\mathrm{N}\left(\mathrm{g} \cdot \mathrm{m}^{-3}\right)\right]=$ $4.98+1.176 \times$ days $\left(r^{2}=0.99\right)$ for the high $L F$ treatment. In the 45 to $90 \mathrm{~cm}$ soil zone, $\mathrm{NO}_{3}-\mathrm{N}$ levels fluctuated over time; however, neither WA nor LF affected $\mathrm{NO}_{3}-\mathrm{N}$ concentrations at these depths. At this depth in the soil profile, there was no consistent pattern of downward $\mathrm{NO}_{3}-\mathrm{N}$ movement from the overlying treatments and no interactions between $\mathrm{LF}$ and changes in the soil $\mathrm{NO}_{3}-\mathrm{N}$ concentration over time occurred (Fig. 3, Table 3).

\section{Discussion}

In this study, $550 \mathrm{ml}$ was a sufficiently small irrigation volume to produce a LF near 0 when pots were dry; however, when the potting medium was not dry, the LF was as high as 0.3 (Fig. 1A). 
In a previous study (McAvoy et al., 1992), irrigation volume was adjusted at each irrigation based on the calculated LF produced by test pots in an attempt to produce LFs of either 0.1 or 0.5 , and considerable variation between the actual LF and the target LF were still observed. $\mathrm{Ku}$ and Hershey (1992) reported a similar divergence from the target LF. In their study, the actual LF averaged $24 \%$ below the target LF of 0.1 and $8 \%$ below the target LF of 0.4. Together, these data underscore the difficulty of maintaining a constant LF with irrigation volume alone.

LF and nutrient solution concentration are factors that affect leachate and root-zone EC (Ku and Hershey, 1991, 1992; McAvoy et al., 1992; Ruter, 1992; Yelanich and Biernbaum, 1990). However, once the decision is made to reduce LF, fertilizer concentrations must automatically be reduced to prevent excessive nutrient accumulation in the potting medium (provided initial fertility levels were adequate).

From an environmental perspective, LF in the greenhouse setting is important for two reasons. First, it is directly related to total $\mathrm{NO}_{3}-\mathrm{N}$ deposited per irrigation. Second, as it relates to LI, it represents the primary hydraulic load or driving force to move the soluble $\mathrm{NO}_{3}-\mathrm{N}$ load down through the soil profile. Since the product of irrigation frequency and LF bears a direct positive relationship to $\mathrm{LI}$, the cumulative $\mathrm{NO}_{3}-\mathrm{N}$ and hydraulic loads on a soil surface from a constant LF would further increase as irrigation frequency increased.

The best way for a grower to control LI, and thus hydraulic load, is to control LF. For example, with a container capacity of $500 \mathrm{ml}$, an irrigation volume of $555 \mathrm{ml}$ would be required to produce a LF of 0.1 ( $55 \mathrm{ml}$ of leachate) and an irrigation volume of $1000 \mathrm{ml}$ would be required to produce a LF of 0.5 ( $500 \mathrm{ml}$ of leachate). In this example, the irrigation frequency of the high LF would have to decrease 10-fold to produce the same LI as a single irrigation at the low LF. In addition, LF can be readily reduced by modifying cultural practices (i.e., applying less solution per irrigation), but irrigation frequency is largely determined by environmental conditions and plant factors such as total leaf area and specific wateruse efficiency-factors a grower can not easily control.

In the field, $\mathrm{NO}_{3}-\mathrm{N}$ from the leaching of containerized crops is carried through the underlying soil profile by the hydraulic load of the leachate and the hydraulic load from rainfall and, if overhead irrigation is used, the hydraulic load of irrigation water missing the containers. For the greenhouse chrysanthemum crop, the low LF produced a cumulative hydraulic load of $1.5 \mathrm{~cm}$ without WA and $2.1 \mathrm{~cm}$ with WA, while the high LF produced a cumulative

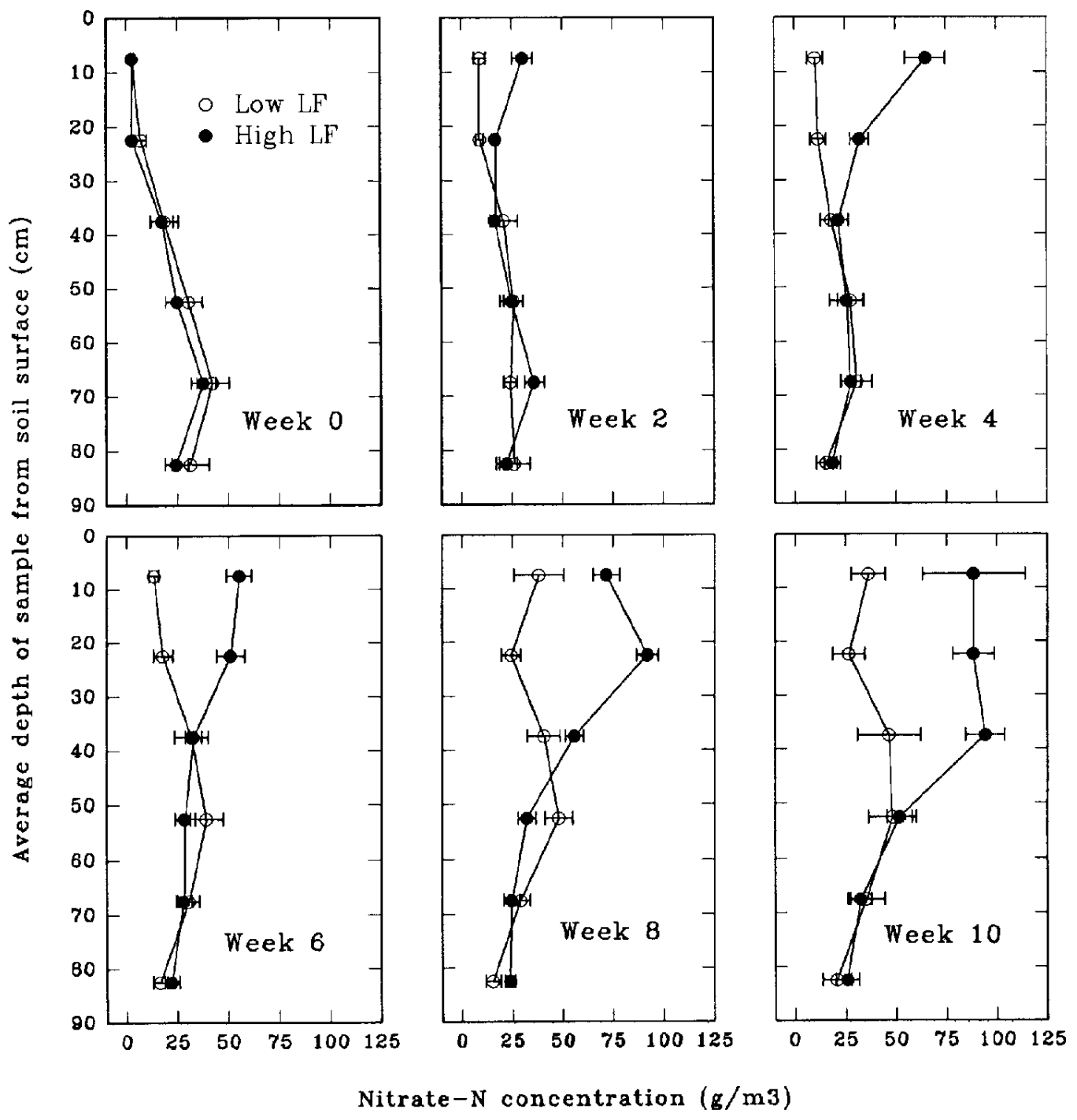

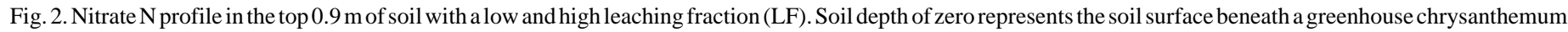

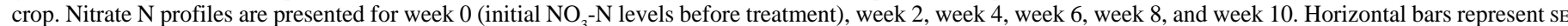
of the means; error bars that do not appear on graphs are smaller than symbols. 


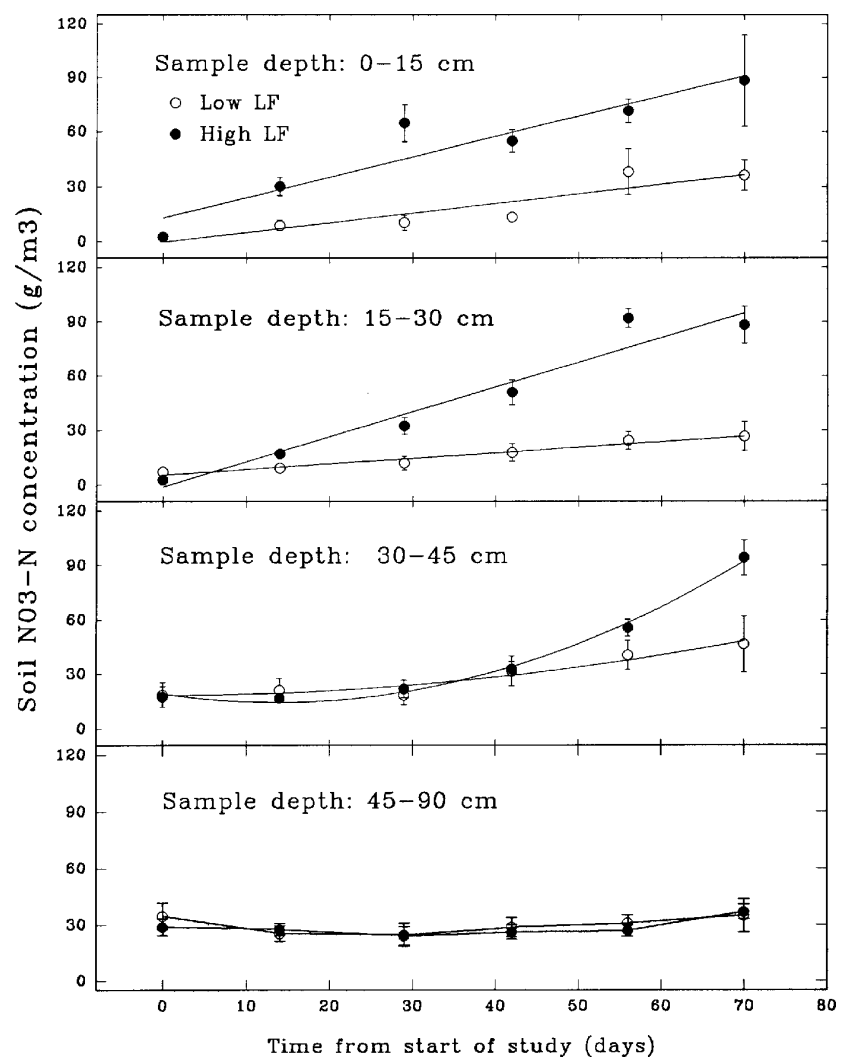

Fig. 3. Temporal change in $\mathrm{NO}_{3}-\mathrm{N}$ concentrations $\left(\mathrm{g} \cdot \mathrm{m}^{-3}\right)$ in the soil under chrysanthemums irrigated with a low or high leaching fraction (LF). Sample depths: 0 to $15 \mathrm{~cm}, 15$ to $30 \mathrm{~cm}, 45$ to $90 \mathrm{~cm}$. Significant $\mathrm{NO}_{3}-\mathrm{N}$ accumulation rates are defined by the following regression equations: 1 ) at the 0 to $15 \mathrm{~cm}$ depth with a low $\mathrm{LF}\left[\mathrm{NO}_{3}-\mathrm{N}\left(\mathrm{g} \cdot \mathrm{m}^{-3}\right)\right]=-0.316+0.527 \times$ days, $r^{2}=0.91$; with a high $\mathrm{LF}$ $\left[\mathrm{NO}_{3}-\mathrm{N}\left(\mathrm{g} \cdot \mathrm{m}^{-3}\right)\right]=12.83+1.117 \times$ days, $\left.r^{2}=0.94 ; 2\right)$ at the 15 to $30 \mathrm{~cm}$ depth with a low $\mathrm{LF}\left[\mathrm{NO}_{3}-\mathrm{N}\left(\mathrm{g} \cdot \mathrm{m}^{-3}\right)\right]=5.476+0.302 \times$ days, $r^{2}=0.98$; with a high $\mathrm{LF}\left[\mathrm{NO}_{3}-\right.$ $\left.\mathrm{N}\left(\mathrm{g} \cdot \mathrm{m}^{-3}\right)\right]=-0.963+1.369 \times$ days, $\left.r^{2}=0.97 ; 3\right)$ at the 30 to $45 \mathrm{~cm}$ depth with a low $\mathrm{LF}\left[\mathrm{NO}_{3}-\mathrm{N}\left(\mathrm{g} \cdot \mathrm{m}^{-3}\right)\right]=18.277+0.004 \times$ days $+0.0061 ¥$ days $^{2}, r^{2}=0.97$; with a high $\mathrm{LF}\left[\mathrm{NO}_{3}-\mathrm{N}\left(\mathrm{g} \cdot \mathrm{m}^{-3}\right)\right]=19.153+0.684 \times$ days $+0.0247 ¥$ days $^{2}, r^{2}=0.99$. Vertical bars represent SE of the means; error bars that do not appear on graphs are smaller than symbols.

hydraulic load of $12.2 \mathrm{~cm}$ without WA and $12.5 \mathrm{~cm}$ with WA over the 10-week study. In comparison, Brand et al. (1993) reported for Mansfield, Conn., that, in addition to the cumulative hydraulic load produced through normal irrigation in the field, rainfall contributed $26.5 \mathrm{~cm}$ of water to the soil profile during a typical $14-$ week period, with $11.4 \mathrm{~cm}$ falling in a single week.

Based on previous research (McAvoy et al., 1992) and these data, the downward movement of $\mathrm{NO}_{3}-\mathrm{N}$ through the soil in the greenhouse is restricted by a limited hydraulic load. In these studies, leachate volume was sufficient to cause $\mathrm{NO}_{3}-\mathrm{N}$ to accumulate in the 30 to $45 \mathrm{~cm}$ soil depth but not deeper. Hydraulic load, and subsequent leachate penetration, would be expected to decrease as evaporation from the soil surface increased. In the greenhouse, the air is typically warmer than outside and is constantly moved; therefore, evaporation in the greenhouse may be higher on a yearly basis than in the field.

The rate of $\mathrm{NO}_{3}-\mathrm{N}$ accumulation observed in the 0 to $45 \mathrm{~cm}$ soil profile in this study (Fig. 3) would explain the extremely high $\mathrm{NO}_{3}-\mathrm{N}$ levels measured under old greenhouse ranges (McAvoy, 1991; Molitor, 1990). Assuming $\mathrm{NO}_{3}-\mathrm{N}$ continued to accumulate at a linear rate in the 0 to $45 \mathrm{~cm}$ layers as observed in this study, 440 days would be required for the $\mathrm{NO}_{3}-\mathrm{N}$ concentration in a cubic meter of soil beneath the high LF to exceed the 230-g level observed beneath old greenhouse ranges in Connecticut (McAvoy,
1991). With the low $\mathrm{LF}, \mathrm{NO}_{3}-\mathrm{N}$ accumulation would exceed this level in 1210 days of continuous cropping.

While these $\mathrm{NO}_{3}-\mathrm{N}$ accumulation rates are very high, the limited leachate penetration observed in this study would suggest that the biggest groundwater threat from greenhouse crop production would occur when the water table was close to the soil surface (i.e., within $1 \mathrm{~m}$ ), or the glazing was removed to allow rainfall to act on the accumulated $\mathrm{NO}_{3}-\mathrm{N}$ in the soil profile, or LI was dramatically increased. This conclusion does not diminish the importance of reducing LF, and thus LI, for greenhouse crops. With lower LFs, the amount of fertilizer applied to a crop could typically be reduced, often with beneficial effects on crop quality. Also, substantial reductions in total $\mathrm{NO}_{3}-\mathrm{N}$ deposition, hydraulic loading, and leachate penetration through the soil profile would result.

\section{Literature Cited}

Brand, M.H., R.J. McAvoy, and E.G. Corbett. 1993. Nitrate loading to the soil profile underlying two containerized nursery crops supplied controlled release fertilizer. J. Environ. Hort. 11(2):82-85.

Cox, D.A. 1993. Reducing nitrogen leaching-losses from containerized plants: The effectiveness of controlled-release fertilizers. J. Plant Nutr. 16:533-545.

Elliott, G.C. 1992. Imbibition of rockwool-peat container media amended with hydrophilic gel or wetting agent. J. Amer. Soc. Hort. Sci. 117:757761.

Gomez, K.A. and A.A. Gomez. 1984. Statistical procedures for agricultural research. 2nd ed. Wiley, New York.

Hershey, D.R. and J.L. Paul. 1982. Leaching-losses of nitrogen from pot chrysanthemums with controlled-release or liquid fertilization. Scientia Hort. 17:145-152.

Keeney, D.R. and D.W. Nelson. 1982. Methods of soil analysis: Part 2. Chemical and microbiological properties. 2nd ed. Amer. Soc. Agron., Madison, Wis. p. 643-693.

$\mathrm{Ku}, \mathrm{C} . \mathrm{S} . \mathrm{M}$. and D.R. Hershey. 1991. Leachate electrical conductivity and growth of potted poinsettia with leaching fractions of 0 to 0.4 . J. Amer. Soc. Hort. Sci. 116:802-806.

Ku, C.S.M. and D.R. Hershey. 1992. Leachate electrical conductivity and growth of potted geranium with leaching fractions of 0 to 0.4 . J. Amer. Soc. Hort. Sci. 117:893-897.

McAvoy, R.J. 1991. Greenhouse agriculture and nitrate-nitrogen loading to groundwater. Center Environ. Health Nwsl. 3(2):3-4.

McAvoy, R.J., M.H. Brand, E.G. Corbett, J.W. Bartok, Jr., and A. Botacchi. 1992. Effect of leachate fraction on nitrate loading to the soil profile underlying a greenhouse crop. J. Environ. Hort. 10:167-171.

Molitor, H. 1990. The European perspective with emphasis on subirrigation and recirculation of water and nutrients. Acta Hort. 272:165-173.

Poole, R.T. and C.A. Conover. 1989. Fertilization of four indoor foliage plants with Osmocote or Nutricote. J. Environ. Hort. 7:102-108.

Rathier, T.M. and C.R. Frink. 1989. Nitrate in runoff water from container grown juniper and Alberta spruce under different irrigation and $\mathrm{N}$ fertilization regimes. J. Environ. Hort. 7:32-35.

Ruter, J.M. 1992. Leachate nutrient content and growth of two hollies as influenced by controlled release fertilizers. J. Environ. Hort. 10:162-166. Walker, M. 1990. Cornell University greenhouse study report. New York State Water Resources Inst., Cornell Univ., Ithaca, N.Y. p. 1-12.

Wang, Y-T. and C.A. Boogher. 1987. Effect of medium-incorporated hydrogel on plant growth and water use of two foliage species. J. Environ. Hort. 5:125-127.

Williams, K.A. and P.V. Nelson. 1990. Development of a nutrient source for sustaining low concentrations in greenhouse substrates. HortScience 25:1170. (Abstr.)

Yelanich, M.V. and J.A. Biernbaum. 1990. Effect of fertilizer concentration and method of application on media nutrient content, nitrogen runoff and growth of Euphorbia pulcherrima 'V-14 Glory'. Acta Hort. 272:185-189. 